\title{
Nacht, from Arnold Schoenberg's Pierrot Lunaire: a perspective from the ArtSong Theory on the text-music relationships and its unfoldings
}

\author{
Achille Picchi \\ Universidade Estadual Paulista, Instituto de Artes \\ achillepicchi@gmail.com
}

\begin{abstract}
The cycle of melodramas Pierrot Lunaire op. 21 was written and premiered in 1912 and is one of the capital works of Schoenberg's output as well as of the vocal music in the twentieth-century music. In this article we examine Nacht, the eighth melodrama, first of the second part, due to its relationships on text-music as a factor of influence in the perception and performance of the work. And we also examine the numerical relations that were so dear to the composer.
\end{abstract}

Keywords: Pierrot Lunaire, Schoenberg, Nacht, text-music.

\section{Nacht, do Pierrot Lunaire de Schoenberg: perspectiva das relações texto-música segundo a Teoria da Canção de Câmara e seus desdobramentos}

Resumo: O ciclo de melodramas Pierrot Lunaire op.21 foi escrito e estreado em 1912 e é uma das obras capitais da produção de Schoenberg assim como uma das principais obras de música vocal do século XX. Neste artigo examinamos Nacht, o oitavo melodrama, primeiro da segunda parte, nas relações texto-música como um fator de influência na percepção e performance da obra. E também das relações numéricas que eram tão caras ao compositor.

Palavras-Chave: Pierrot Lunaire, Schoenberg, Nacht, texto-música.

\section{Introduction}

This is an informed opinion and personal consideration about Pierrot Lunaire, the op. 21 by Arnold Schoenberg, and its relationships on text-music linked to intentionality and ultimately the role of number.

Concerning text-music, I've chose Nacht, the eighth melodrama and first song of the second part, around which I've make observations relative to my theory of art song towards the understanding of it.

First, though, I'll make a brief digression over my point of view on text-music and intentionality. 


\section{Text-Music}

In the establishing an art song theory I believe that the idea of text-music is a very important concept in the knowledge of what vocal music should be in his own sake, as 'vocality' plus integrality considering all means on which its developing is going on. For me this is an indivisible whole in the entire creative treatment.

I call 'musication'1 (musicação, in Portuguese), the act of setting music to a text, be it poetic or not, with the straightforward intention that it will be sung, or similarly, expressed differently from a normal speech. This means that any reading that a composer makes of a poetic text which he intends to 'musicate' (musicar), it is not a common one, not just a regular reading, understanding, comprehension, because it is really fulfilled of musical 'preoccupations', i.e., intentions, that are intrinsically linked to his technical repertoire, life and cultural experience, talent, as well as perception of details care for his creative process, like word soundings, repetition ideas, form and shape of the text, images, etc. In summary, verbaliconic and imagetic stimulations or, in other words, representation and symbolization.

It is well known that Schoenberg doesn't know about Albert Giraud, the Belgian symbolist poet, and his poems, which include Pierrot Lunaire, till the singer-actress of the Überbretl Theater commissioned him to set music to the poems in order to make a recital tour. Schoenberg accepts the task with enthusiasm and interest and selects 21 poems to make a cycle.

The translation to German (or transduction, as maybe would say the poet and translator Haroldo de Campos) is the only poetic text to be considered as a basis for the musication that Schoenberg undertakes, even if he eventually has been in contact with the French originals.

This is, finally, very important because I believe that exists, as already mentioned, two great paths for musication inside the reading (or maybe perusal of it) the composer makes: one is representation, the other is symbolization. Both induce musically the imagination and the techniques of the creator that he transports to sounds, including those beyond the voice.

It is curious to observe how vocal music, along the 20th century, was an impulse for the musical Avant Garde. And is possible to say that the melodramas of Schoenberg's opus 21, the Pierrot Lunaire, was an initial mark stone to push the same Avant Garde on. Besides, somehow

\footnotetext{
${ }^{1}$ That is a neologism which is presented in my book PICCHI, 2019.
} 
it was a boost in the camera vocal music with instruments differently of the romanticism with its art song with piano.

The Pierrot Lunaire effectively represents a fracture in the history of western musical history.

Compositions with text constitute most of the Schoenberg's output, including his tonal period to atonal and dodecaphonic ones.

Schoenberg, as known, always underlined the role of music as messenger carry on over vocal works. But he knows, tough, the importance of the text in the integrality of the vocal work for, as he himself said, "songs, opera and oratorios don't simply would exist in music if wouldn't be added to them the highest expression of their texts. Besides, how to be sure that your music doesn't express anything - or even more: doesn't express something provoked by your text".

The text is a factor that, despite being external, is a fundamental one in the conceptual stage of the composition. It influences, undoubtedly, form, character, and other creative ways. Embedded in the music the texts engender a vaster totality whose meaning is, by this way, another one.

Those interinfluences and definitions manifests themselves definitely in the intentionality.

\section{Intention and Intentionality}

To comprehend intention and intentionality on vocal works of music imports to consider three basic questions: 1) it's always possible to know the composer's intention; 2) the intentionality is expressed on the musical text; and 3) there's always the possible mediation of the musical intentionality as a renew intention,

The intention is an action of the will. Someone that do something intentionally is aware of one's action and do it using the choice to do it, i.e., by volition. Departing from the fact that choices exist and must (or want) to be completed, there is an intentional relation over them and this relation implies a will content. That is, the volition has always a content and acting intentionally means satisfying this 'volitile' content. 
In the case of music - especially in the vocal works - this realization of the conditions of intentional satisfaction that relates volition and action is the primeval stimulation to the composing work, which is the writing (l'écrite).

The composer that always have a specific compositional intention around a 'volitive' choice, directs himself to a conscientious writing down of this intention as a mean of definition. Doing so, he leaves a track, a pathway of his intentional mental state, transforming all those things into a intentionality: the score.

Thus, the intentionality is the expression of the last intentional compositional choice worked out as a text, where resides a field of significations. The score overlooks two stances: the writing (l'écrite), a selection of a code and all its implications and relationships; and the 'ecriture' (l'écriture), which means roughly what lay behind the code, or syntactic and grammar processes and beyond them, those things that reside between the code and the sound: the music ${ }^{2}$.

The choices made in musication undertaken by the composer to musicate a poetic text lead him to intentional choice actions directed to the selected intentionality through technical/expressive workout of the musical text, becoming, through l'écriture, musical ontology. Therefore, by means of intentionality, the score becomes a map providing a great number of interpretations which will be made always a posteriori and with attribution of meaning. This attribution is due specially to analysis. There isn't, therefore, mediation without text and departing from it will be the principal task of interpretation, provided that an interpretative execution leading to a fore performance is onto objective.

In the intentionality proposed by the composer in the Pierrot, it also appears a specific vocality.

\section{Vocality}

The consecution of sound in speech transforms itself in vocal sign and symbol. The voice is emission, intonation, volume, extension, dynamics. When organized, it originates the discourse.

\footnotetext{
${ }^{2}$ Concerning écrite and ecriture, cf. DERRIDA, 2008.
} 
Roland Barthes (1995) located a materiality in the voice, due to its relationships with the discourse. Even though it is not possible to identify a physicality of the voice, undoubtedly its existence is due to an abstraction conducted by a sounding vehicle functioning as expressivity.

The singing voice related to the vocal work of music hosts a specific vocality, i.e., the attributes of the existence of the voice: emission, intonation, timbre, etc. It represents decisively choosing processes.

The vocality encompasses everything the voice is able to realize, to show or to express, including itself. And this concept goes beyond qualities like timbre and practice and considers everything that is being vocalized, sounded, and identified as vocal by auditory means by far the words (discourse) that illustrates it - and generates the text - or even beyond its techniques or its colors.

Schoenberg, notoriously, opted by the sprechgesang vocality in the Pierrot. It doesn't represent exactly a novelty, since from the late 1890's was already a vocal resource used by composers; the same Schoenberg used it in previous compositions.

Beyond the fact that novelty (or the new) does not exist as a metaphysical being-there (Dasein), only whereas originality along the unfolding of time which crystalizes a past that will represents the new, the op.21 stands for a fracture in western music, as I've already put it, in terms of the systematic and continued use of the sprechgesang. The placing of a synthesis theatrical/vocal in the sense of orality/'cantability' (referring to a cantabile sense), sets the pure expression - and like it, the original in a unique state.

Sprechgesang truthfully wasn't a term employed by Schoenberg in the Pierrot Lunaire, just sprechstimme, speaking voice roughly. He employed other terms too, less often, like gesungen - sung, gesprochen - speaking, and geflüsterd - whispered.

Sprechgesang could be translated as a manner of singing, a kind of 'parlando', sometimes even could be translated as recitativo. An important composer and musical thinker as Flo Menezes say that there is a proximity between the recitativo and the sprechgesang and goes further to the fact that perhaps it is due to a typically "expressionist" interpretation full of 'gestuality' ${ }^{3}$. As we have seen above, in fact is possible to the German language translate - or

\footnotetext{
${ }^{3}$ I.e., due to gesture. To see this discussion, cf. MENEZES, 2002, pp.137-145.
} 
understand - sprechgesang as recitativo; but, I think, not really as 'rezitation' as written by Schoenberg, which differentiates things even more.

All this allows me to disagree a little bit from that important composer/thinker in the interpretative sense. As known, in the Preface of the op. 21 Schoenberg establish some "instructions" how to perform the sprechstimme; nonetheless they are not exactly clear or even precise, provoking many problems ever after. Let us just not forget the fondness Schoenberg had to the paradox... beginning with the statement Pierrot Lunaire ist nicht zu singen!

Flo Menezes also says that the bottom line of the problem may be, obviously, the relationship between the speaking and the singing, and that's what I agree with. But he goes on saying that what exists, really, is an exaggerated intonation beyond the limits of speaking and before the limits of singing. And that I don't think so. A detailed analysis can and will demonstrate the quantum Schoenberg tried a specular amplification of a real vocality, inventive in the symbiotic sense, which keep all the characteristics prolatives of the speech and 'entonative' of singing in a unique totality for this masterpiece.

The text-music categorizations and of the vocality are kept under a new drapery, maybe confirming his idea of being an heir e follower of the great German music tradition, classic and romantic - in the latter case with the voice as a representative, together with the language, of a cultural identity that he thought fundamental. On being like this, he was an inevitable historical force.

\section{Textual Analysis}

In order to provide some exemplifications to my ideas of text-music and intentionality, I chose Nacht, the eighth song of the cycle, the first one of the second part of Pierrot Lunaire, to analyze.

This analysis, that belong to my art song theory, is divided in four parts, called Structures: Rhythmic Structure, Metric Structure, Strophic Structure and Sonic Structure, and refers to the poem in the first stance. After that I realize a connection with the music through the text-music embedded with the previous textual analysis ${ }^{4}$.

\footnotetext{
${ }^{4}$ This kind of analysis is described in PICCHI, 2019.
} 


\section{Rhythmic Structure}

The rhythmic structure studies the ictus and tonic accentuations, the proper and the dislocated ones. There is a relation between ictus and tonic accentuation, indicating the stressing of verses regarding the verse as a whole.

Tab. 1 Rhythmical Structure of Nacht.

\begin{tabular}{|c|c|c|}
\hline ICTOS & VERSE TONIC & $\begin{array}{c}\text { PHRASAL RHYTHM } \\
\text { /SONG } \\
\end{array}$ \\
\hline Finstre, Schwartze, Riesenfalter & $1^{\mathrm{o}}, 3^{\mathrm{o}},\left(5^{\mathrm{o}}\right) 7^{\mathrm{o}}$ & $1^{\mathrm{o}}, 3^{\mathrm{o}}, 5^{\mathrm{o}} .7^{\mathrm{o}}$ \\
\hline Tötenten der Sonne Glanz & $1^{\mathrm{o}}, 5^{\mathrm{o}}, 7^{\mathrm{o}}$ & $1^{\circ}, 5^{\circ} 7^{\circ}$ \\
\hline Ein Geschlossness Zauberbuch & $\left(1^{\circ}\right), 3^{\circ}, 5^{\circ}, 7^{o}$ & $3^{\circ}, 5^{\circ}, 7^{\circ}$ \\
\hline Ruth der Horizont verschwingen & $1^{\circ}, 3^{\circ}, 5^{\circ}$ & $1^{\circ}, 3^{\circ}, 5^{\circ}, 7^{\circ}\left(8^{\circ}\right.$ coda $)$ \\
\hline Aus der Qualm verlorner Tiefen & $3^{\circ},\left(5^{\circ}\right), 7^{\circ}$ & $3^{\circ}, 5^{\circ}, 7^{\circ}$ \\
\hline $\begin{array}{l}\text { Steigt eein Duft Erinnrung } \\
\text { mordent! }\end{array}$ & $1^{\circ}, 3^{\circ}, 7^{\circ}$ & $3^{\circ}$ (prolong.), $6^{\circ}, 7^{\circ}$ (brief) \\
\hline Finstre, Schwartze, Riesenfalter & $1^{\mathrm{o}}, 3^{\mathrm{o}},\left(5^{\mathrm{o}}\right) 7^{\mathrm{o}}$ & $1^{\mathrm{o}}, 3^{\mathrm{o}}, 5^{\mathrm{o}} .7^{\mathrm{o}}$ \\
\hline Tötenten der Sonne Glanz & $1^{\circ}, 5^{\circ}, 7^{\circ}$ & $1^{\circ}, 5^{\circ} 7^{\circ}$ \\
\hline Und von Himmel erdenwärts & $\left(1^{\circ}\right), 3^{o},\left(5^{\circ}\right), 7^{o}$ & $3^{\circ}, 5^{\circ},\left(7^{\circ}\right.$ brief $)$ \\
\hline $\begin{array}{l}\text { Senken sich mit schweren } \\
\text { Schwingen }\end{array}$ & $1^{\mathrm{o}}, 3^{\mathrm{o}}, 5^{\mathrm{o}}, 7^{\mathrm{o}}$ & $1^{\mathrm{o}}, 5^{\mathrm{o}}, 7^{\mathrm{o}}$ \\
\hline Unsichtbar die Ungetüme & $\left(1^{\circ}\right), 3^{\circ}, 5^{\circ}, 7^{\circ}$ & $1^{\circ}, 3^{\circ}, 5^{\circ},\left(7^{\circ}\right.$ brief $)$ \\
\hline Auf die Menschenherzen nieder & $\left(1^{\circ}\right), 3^{\circ}, 5^{\circ}, 7^{\circ}$ & $3^{\circ}, 5^{\circ}, 7^{\circ}$ \\
\hline Finstre, Schwartze, Riesenfalter & $1^{\mathrm{o}}, 3^{\mathrm{o}},\left(5^{\mathrm{o}}\right) 7^{\mathrm{o}}$ & $1^{\mathrm{o}}, 3^{\mathrm{o}}, 5^{\mathrm{o}} .7^{\mathrm{o}}$ \\
\hline
\end{tabular}

Source - Author's Elaboration.

Nacht is a heptasyllabic 'heterorrhythmic' poem, which means that regarding accentuation there is a tendency to the $7^{\circ}$ syllable always. Nonetheless we can observe the $1^{\circ}$, $3^{\circ}$ and $7^{\circ}$ syllables as more frequent in the poem and the $5^{\circ}$, less frequent; as well as the musication goes primarily to $3^{\circ}, 5^{\circ}$ and $7^{\circ}$ syllables in 'agogics'.

\section{Metrical Structure}

The metrical structure studies the 'versal' scansion and the situation of the metrical feet. A metrical foot is constituted by a certain number of syllables and letters that it contains. To be effective, the counting of metrical feet is based in the tonicity of the syllables, i.e., the major accentual one relatively to a minor one. 
The scansion takes into account the sonorous fluidity and its importance to the rhythm of the verse as well as the rhythmical combination in musication.

Tab.2 Metrical Structure of Nacht.

\begin{tabular}{l|c|c}
\hline \multicolumn{1}{c|}{ METRICAL FEET } & METRIC CELLS & VERSE \\
\hline $\begin{array}{l}\text { Finstre, Schwartze, Riesenfalter } \\
\text { /-/---/ }\end{array}$ & trochee, peon primus, trochee & \\
\hline $\begin{array}{l}\text { Tötenten der Sonne Glanz } \\
\text {--- /-- }\end{array}$ & peon primus, dactyl & $\mathrm{H}$ \\
\hline $\begin{array}{l}\text { Ein Geschlossness Zauberbuch } \\
--/ \text {---/ }\end{array}$ & anapest, peon quartus & $\mathrm{E}$ \\
\hline $\begin{array}{l}\text { Ruth der Horizont verschwingen } \\
\text { /---/-/- }\end{array}$ & peon primus, trochee, trochee & $\mathrm{T}$ \\
\hline $\begin{array}{l}\text { Aus der Qualm verlorner Tiefen } \\
--/---/\end{array}$ & anapest, peon quartus & $\mathrm{E}$ \\
\hline $\begin{array}{l}\text { Steigt eein Duft Erinnrung mordent! } \\
--/---/\end{array}$ & anapest, peon quartus & $\mathrm{R}$ \\
\hline $\begin{array}{l}\text { Finstre, Schwartze, Riesenfalter } \\
\text { /-/---/ }\end{array}$ & trochee, péon primus, trochee & $\mathrm{O}$ \\
\hline $\begin{array}{l}\text { Tötenten der Sonne Glanz } \\
\text { /---/-- }\end{array}$ & peon primus, dactyl & $\mathrm{M}$ \\
\hline $\begin{array}{l}\text { Und von Himmel erdenwärts } \\
--/---/\end{array}$ & anapest, peon quartus & $\mathrm{E}$ \\
\hline $\begin{array}{l}\text { Senken sich mit schweren Schwingen } \\
\text { /---/-/- }\end{array}$ & peon primus, trochee, trochee & $\mathrm{T}$ \\
\hline $\begin{array}{l}\text { Unsichtbar die Ungetüme } \\
--/---/\end{array}$ & anapest, peon quartus & $\mathrm{R}$ \\
\hline $\begin{array}{l}\text { Auf die Menschenherzen nieder } \\
--/---/\end{array}$ & anapest, peon quartus & $\mathrm{I}$ \\
\hline $\begin{array}{l}\text { Finstre, Schwartze, Riesenfalter } \\
\text { /-/- --/ }\end{array}$ & trochee, péon primus, trochee & $\mathrm{C}$ \\
\hline
\end{tabular}

Source - Author's Elaboration.

As we can see in Table 2, the predominance of trochee, strong/weak and peon quartus, weak, weak, weak/strong give us an idea of the use of the composer in Pierrot. The first figure, used unconsciously and regularly, shows us a rhythm very ordinary and common in the configuration of the Carnevale di Venezia figures, especially Pierrot, Arlecchino and Pantalone. We can see this, for instance, in the beginning of Gebet am Pierrot (the trochee as an exclamation!). But not the second one, though. Surprisingly the anapest, weak, weak/strong is the 'agogic' more used by the composer, as, for example, contrary to the dactyl of Sonne Glanz of the poem. 
The voice sings Verschwingen with the moth-motive in the low region. In the poem we have two trochees in the metric, but due to the significant gesture of secret, or discreet or silent, the composer made it with three accents, strong, strong, strong, equivalent in poetry to a figure named 'molossus' which is used in cases of extreme emotional term (ff or pp, as in this case), revealing the theatrical sense of the text-music here.

\section{Strophic Structure}

The strophic structure studies the grouping of the verses that forms a unity in the conception of the poet (or, sometimes, the traditional poetic forms). This grouping is called stanza. Depending on the poem, there is the isotrophic poem, when the grouping of stanzas is a regular one, or 'alostrophic' poem, when it is irregular.

It is important to understand of this conception to the formal thought of the composition.

Tab.3: Strophic Structure of Nacht

\begin{tabular}{c|c}
\hline & Introduction: $\mathrm{m} .1-3$ \\
\hline ALOSTROPHIC & Section I: v.1-4, m.4-10 \\
\hline POEM & $\begin{array}{c}\text { Section II: v.5-8, m.11-16 (with a bridging } \\
\text { m.17 as a little introduction to section III) }\end{array}$ \\
\hline Cection III: v.9-12, m. 17-22 \\
Coda: v.13, and m.23-26, instrumental
\end{tabular}

Source - Author's Elaboration.

We can observe that since the poem has three stanzas, Schoenberg organized his format in three parts, including an attention stop on Verschwingen where the motive is, in thirds, or the moth-motive, measure 10 .

He introduces the second section with a modification on tempo (etwas rascher) and the third with a new modification of tempo (tempo primo), as a return to previous spirits. Before the third part, a tremolo fff in the piano makes the same attentive stop; but now with the recitation of the text in an ironic and 'stentoric' mood (Finstre, schwarze Riesenfalter). The clearance of movement by the augmentation of figure values, thus provoking a written ritenuto, takes place as a remembrance of the beginning, exerting the role of a coda and completing, in so doing, the symmetry or the discourse perceived by the listener. 


\section{Sonic Structure}

The sonic structure studies the sounding coincidences, internal and external, of all kinds, especially rhymes. It is a complimentary point for textual analysis where we can see if sound patterns and its respective coincidences emulate the sonic imagination of the composer, even if he intends to use them in a obvious way.

In Nacht Schoenberg didn't have any preoccupation, compositional or other, with it. But all along the Pierrot he has often used it.

\section{Numbers}

As a Jew, Schoenberg has had all his life a great commitment with religion (alternating periods of crisis and calm) - but specially with the mystic of it. And one of the facts that can realize it is the liaison with the number, symbolic and literal.

Despite the serious uses that Schonberg makes of it, here I want to deliver some curiosities on the matter.

All his life Schoenberg was fascinated by the numerology and believed that the complex calculations over the numbers and letters which provided interpretations were a powerful source of knowledge. This was tightly linked with the Gematria, a branch of the Jewish Kabballah.

He was so convinced of that, that once he complained with a friend who blamed him for his believes saying that it was not a Kinderspiel (scherzo infantile, as he referred later) but something very serious indeed.

In the Jewish tradition the 3 and the 7 plays an important role in the Kabballah. Their signification goes like: for 3 , the unification of contraries a harmony; for 7 , mysticism, introjection. The sum of them means the great number, the 10 or elevation and wise. And Schoenberg paid a great respect for all this. So, in the Pierrot we can see it.

Schoenberg subtitled the Pierrot Lunaire as Three Times Seven Poems as his choice for the cycle. The idea of 21 poems suggests the inverse of 12, another important number in Jewish tradition which occurs in all written texts, number of opus and in an exact counterimage of the year of composition, 1912. Coincidences? Well...

The numbers 3 and 7 and their correlatives dominates Nacht in the Pierrot. 
We can begin with the moth motive which is composed of thirds one minor another major. His first appearance, in an ascendant form, suggests the triangle - and its transformations alike. This triangle also suggests, as some analysts have pointed out, the form of the moth.

The variations, in general, are multiples of 3 , as figuration and disposition. The secondary motive, a chromatic scale is a line of six notes, or 3 plus 3.

The poems chosen all are written in a rondeaux form, having 3 stanzas each with 4 verses, and the 21 of them added result 84, which summed up and reduced give us 12 , number that, summed up again gives 3 .

The ensemble of instruments is composed of voice, five instruments and a conductor, total 7. That is what possibly allows us to say that is the reason because the composer chose the alternative instruments for the same instrumentalist.

Formally Nacht is composed like 3 measures of introduction; 7 measures of Section I; 6 measures ( 2 three times) Section II; 7 measures Section III; 3 measures Coda.

The use of 3 and 7 is disseminated all over the Pierrot Lunaire. And other works too.

Schoenberg abhorred the 13. Maybe because he was born in September 13th, 1874 (a Freudian case, perhaps?) And fate did not cease, in his tricky way, to cross paths with our composer. He died in July 13th, 1951. And even more thirteens: he passed away precisely at 11:47 pm of a Friday, 13, or thirteen minutes to midnight.

To finish with, if you sum up all letters of his entire name (Arnold Franz Walter Schoenberg), transformed in numbers by the traditional numerology, you will obtain 31, which is the inverse of $13 \ldots$

But, after all, as once said Leibniz, music is nothing more than a secret exercise of arithmetic that is manipulated by whom that ignores that is manipulating numbers. Or, in this case, knows it. Very well.

\section{Final Considerations}

Few artists of our time are so stimulant to the spirit as Much as Schoenberg is - and his music witnesses this statement clearly.

He felt in himself, like sometimes he declared, the weight of History of Music, in the sense of some straightforward continuation of the great Austro-Germanic tradition. And this 
means especially on the grounds of his direction to a near future, with the ideas that he considered fundamental to understand music as a life fact: with logic, coherence, and comprehensiveness. In other words, the structural comprehension of major works. He aimed basically and with insistence to modify the way people listen and understand music by making them understand its architecture, really an 'illuministic' ideal, yes, if you want; but nor an unrealistic one, and present in his output and manufacture as well in his aesthetics.

His obsessive use of techniques that, according to him, could be listen to in order to create interest in the work of art is totally transparent in the Pierrot Lunaire. For example, in the cut out that I've made, the song Nacht, we can observe this obsession in action by means of the exhaustive use of transformations of the principal motive, variations, extensiveness, fragmentations, figurations, intricate melodic and harmonic contrapunctual techniques (especially with the secondary motive), like any other traditional oeuvre, all in all to ask us for commitment, compromise, involvement with his effort to deliver a work of art. And assure us how the great tradition, as well as a great dilemma, exerted on him its real historic weight.

Here is presented a synthesis taken from an article by Kathryn Puffet (2006, p.2-22) showing the working out of the motive: 


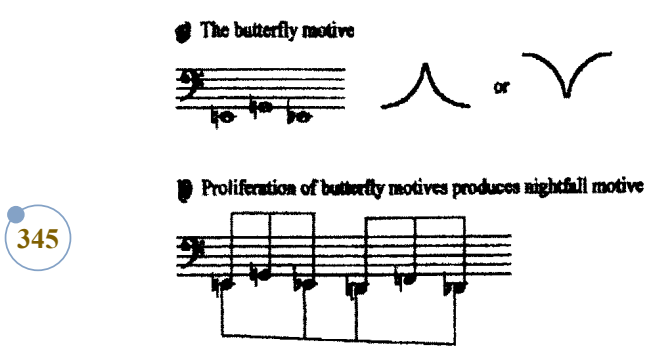

- Toud chale of bumerty motives
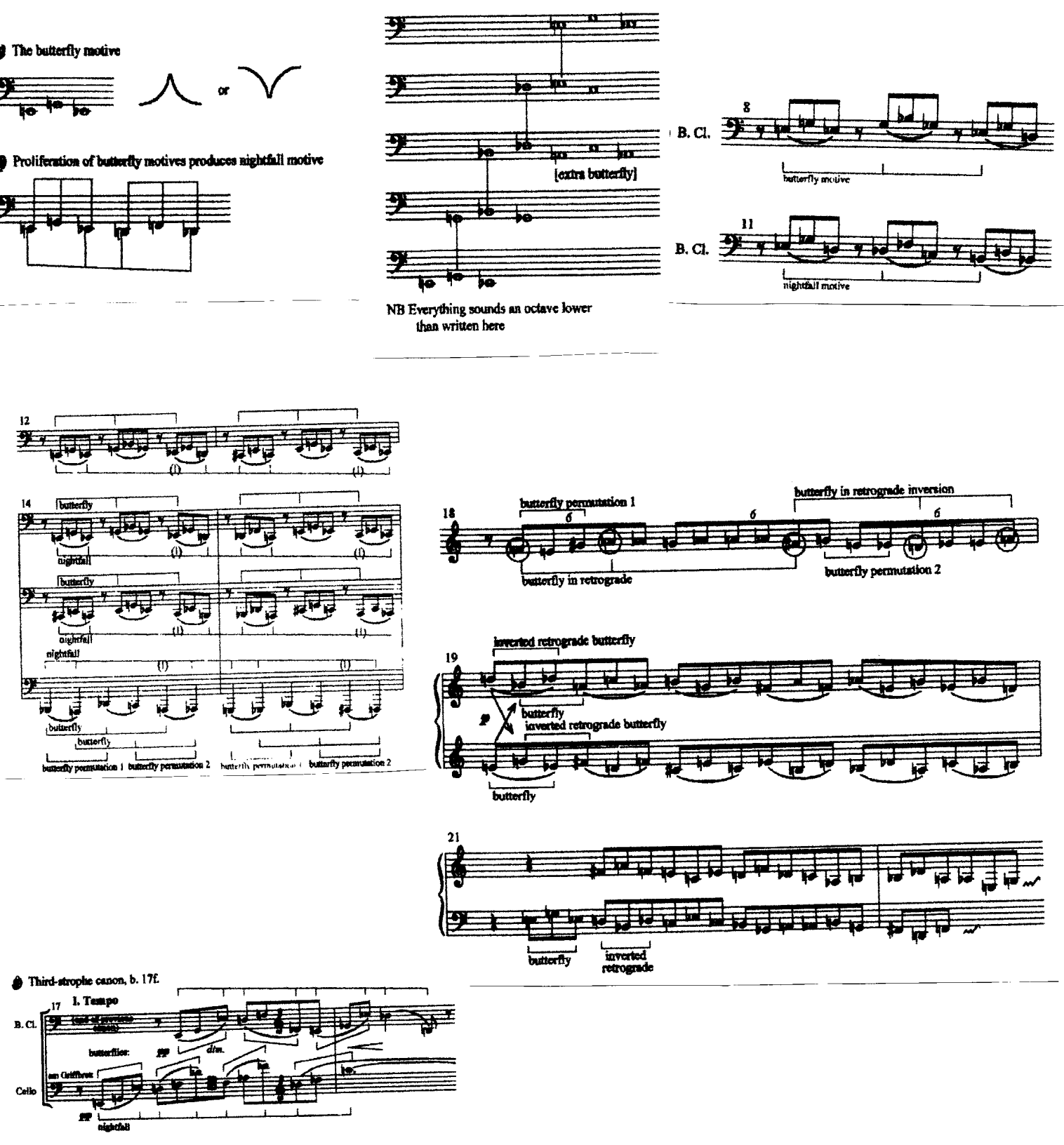

- Buterdy and betterly permatution, b. 176
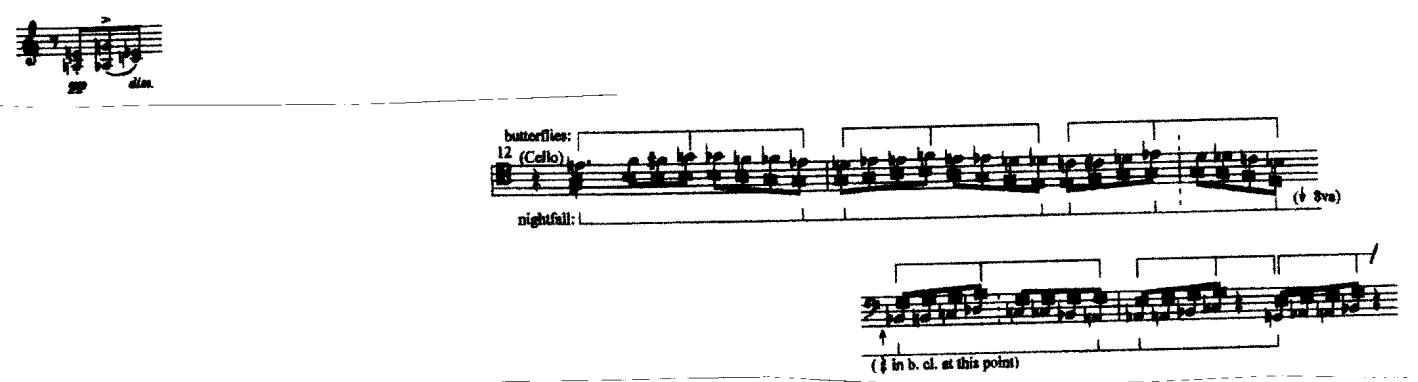
Schoenberg, as a genius composer and original thinker, cared about beauty as much as any classic philosopher-musician in history before him did.

The great aesthetician and philosopher of art Luc Ferry (1994), in his book HOMO AESTHETICUS says that the Pierrot pretended to be a breakthrough in the idea of beauty, understood as harmonic synthesis of a multitude of sounds. I couldn't disagree more. Looking to and analyzing Pierrot I could devise the principle of symmetry, adjustment and complex organization, number, internal harmony, use of all the possibilities of polyphonic counterpoint. The whole of this open Zauberbuch allowed me to think that Lunaire is really a resignification of beauty itself as a renew of rearrangements of the same secular sounds in absolute new possibilities. The choice of a new vocal technique, in a systematic way as he did from the op.21 on, was clearly a departure point for extended techniques not only in the voice terrains but instrumental ones too.

Pierrot Lunaire as whole represents a new attitude towards the beauty in its own sake, in the sense of a relocation between the equilibrium and the organized chaos.

\section{References}

BARTHES, Roland. El obvio y el obtuso. Barcelona: Paidós, 1995.

DERRIDA, Jacques. Da Gramatologia. São Paulo: Perspectiva, 2008.

FERRY, Luc. Homo Aestheticus: A invenção do gosto na era democrática. Trad. Eliana Maria de Melo Souza. São Paulo: Ensaio, 1994.

MENEZES, Flo. Apoteose de Schoenberg 2 ed. São Paulo: Ateliê Editorial, 2002.

PICCHI, Achille G. Canção de Camera Brasileira: Percurso, Análise, Interpretação. Rio de Janeiro: Autografia, 2019.

PUFFET, Kathryn. Structural Imagery: "Pierrot Lunaire” revisited. In: Tempo, n²37, jul. 2006, p.2-22. 